\title{
Temperature sensitivity of transposition of class II transposons
}

\author{
A. K. Turner, ${ }^{1}$ F. De la CruZ $^{2}$ and J. Grinsted ${ }^{1 *}$ \\ ${ }^{1}$ Department of Microbiology, University of Bristol, Medical School, University Walk, Bristol BS8 1TD, UK \\ ${ }^{2}$ Departamento de Biologia Molecular, Facultad de Medicina, Universidad de Cantabria, 39011 Santander, Spain
}

(Received 17 July 1989; revised 15 September 1989; accepted 20 September 1989)

\begin{abstract}
It has been reported that transposition of $\mathrm{Tn} 3$ is temperature-sensitive. The effect of temperature on the transposition of other class II bacterial transposable elements is reported here: Tn21, Tn501, Tn1721, Tn2501 and Tn3926 all also display temperature-sensitivity of transposition. The temperature at which the highest transposition frequency was observed varied between room temperature and $30{ }^{\circ} \mathrm{C}$.
\end{abstract}

\section{Introduction}

Transposable elements are segments of DNA that can be inserted into different locations ('transposed') in the genome of cells. Transposable elements from bacteria can be divided into three classes (Kleckner, 1981). Class II, also known as the Tn3-like transposons, are a group of evolutionarily-related elements (Sherratt, 1989). They are bounded by 38 bp inverted repeats (IRs) and have a transposase (tnp A) gene of about $3 \mathrm{~kb}$; most also contain a resolvase $(\operatorname{tnp} R)$ gene, and have an internal resolution (res) site, at which the resolvase acts. Most, but not all, also encode selectable markers such as resistance to antibiotics. With these class II elements, the transposition event involves recognition of the IRs by the transposase, usually leading to the formation of a cointegrate of the donor and recipient replicons with a copy of the element at each junction. The cointegrate is then resolved into the new recombinant and the original donor by the resolvase.

Transposition of the class II transposon $\mathrm{Tn} 3$ is temperature-sensitive, very little transposition occurring at temperatures above $35^{\circ} \mathrm{C}$ (Kretschmer \& Cohen, 1979); with $\operatorname{Tn} 1000(\gamma \delta)$, the transposition frequency is highest at $37^{\circ} \mathrm{C}$ (Tsai et al., 1987). These two elements represent one sub-class of class II elements; another subclass, typified by Tn21 (de la Cruz \& Grinsted, 1982), contains elements that are rather different from $\operatorname{Tn} 3$. Here we show that $\operatorname{Tn} 21$ itself and the closely-related elements Tn501, Tn1721 (Grinsted et al., 1982) and Tn3926 (Lett et al., 1985), together with the rather more distantly related Tn2501 (Michiels et al., 1987), all also

Abbreviation: IR, inverted repeat. display temperature dependence of transposition. Obviously, in addition to defining the whole group of class II elements more precisely, these data are important when designing experiments involving transposition of these elements.

\section{Methods}

Cells of Escherichia coli K12 strain UB5201 (pro met gyr A) containing R388 ( $\mathrm{Tp}^{\mathrm{r}} \mathrm{Su}^{\mathrm{r}} \mathrm{Tra}^{+}$) (de la Cruz \& Grinsted, 1982) were transformed to antibiotic resistance with plasmid DNA carrying the transposons to be studied (see Table 1 for plasmids used). Transformed cells were selected on nutrient agar containing appropriate antibiotics at $37^{\circ} \mathrm{C}$. Single colonies from these plates were then streaked out on selective plates that contained antibiotics selecting for all the plasmids in the strains. These plates had been pre-incubated for several hours at the test temperature, and, after inoculation, were then stored at the test temperature for the duration of the experiment.

If transposition of the transposable element occurs in these strains during storage, recombinants of the element and R388 will be formed. These can be detected by mating out: R388 is $\mathrm{Tra}^{+}$, so that the transposon is now also transferable, whereas the original donor plasmid that contains the element is not transferable. Thus, after storage, strains were mated with strain UB1637 (his lys trp rpsL) (de la Cruz \& Grinsted, 1982). Single clones of the strain under test were taken from plates stored at the test temperature and cross-streaked with UB1637 on nutrient agar plates that had been pre-incubated at the test temperature for several hours. The plates were then left overnight (or longer in the case of experiments at room temperature) at the test temperature. The resulting bacterial growth was scraped off the plates, resuspended in water $(1.5 \mathrm{ml})$ and the suspension then serially diluted. Portions of the dilution series were plated on agar plates containing streptomycin $\left(200 \mu \mathrm{g} \mathrm{ml}^{-1}\right)$ and trimethoprim $\left(25 \mu \mathrm{g} \mathrm{ml}^{-1}\right)$ to select for transconjugants of UB1637 containing R388. They were also plated on nutrient agar containing streptomycin and either tetracycline $\left(10 \mu \mathrm{g} \mathrm{ml}^{-1}\right)$ for $\operatorname{Tn} 1721$, carbenicillin $\left(500 \mu \mathrm{g} \mathrm{ml}^{-1}\right)$ for $\mathrm{Tn} 3$, kanamycin $\left(50 \mu \mathrm{g} \mathrm{ml}^{-1}\right)$ for $\mathrm{Tn} 2501$ (see Table 1) or mercurochrome $\left(25 \mu \mathrm{g} \mathrm{ml}^{-1}\right.$ ) for $\operatorname{Tn} 21$, Tn501 and $\operatorname{Tn} 3926$, to select for transconjugants 
carrying the transposon. These plates were incubated overnight at $37^{\circ} \mathrm{C}$. Transposition frequencies were determined by dividing the number of transconjugants carrying the transposon by the number carrying R388.

For each transposon at each temperature, at least six independent clones were usually tested in this way. For each mating, plasmid DNA of at least four transconjugants containing the transposon was examined on agarose gels to check that they contained the expected types of recombinants. In the case of the transposition products obtained from the $\operatorname{Tn} 2501$ derivative used in the experiments (see Table 1) these recombinants were cointegrates since the derivative is TnpR- $\mathrm{Res}^{-}$; in the case of the other transposons, the products were simple insertions of the element into various sites in $R 388$. In addition to ensuring that the recombinants were bona fide transposition products, examination of the fragment patterns of recombinants also showed whether recombinants from a particular experiment were insertions into different sites in the R388 and, thus, products of independent transposition events. This was usually the case, but sometimes all recombinants from a particular mating were identical. It was then assumed that a transposition event had occurred very early during growth of the donor strain at the test temperature, and data obtained from such matings were disregarded on the grounds of being due to one transposition event that had replicated many times, rather than being due to many individual transposition events. [This is the reason why the number of determinations shown in Table 1 for particular transposons at particular temperatures is sometimes less than six (the number of clones tested).]

\section{Results and Discussion}

The data in Table 1 show that the transposition frequency of $\operatorname{Tn} 3$ at $37^{\circ} \mathrm{C}$ is only about $1 \%$ of that at $30^{\circ} \mathrm{C}$, and at $42{ }^{\circ} \mathrm{C}$ the frequency is reduced by a further 1000 -fold. There can be no doubt, then, that transposition of $\operatorname{Tn} 3$ is temperature-sensitive, as has been reported (Kretschmer \& Cohen, 1979). However, the data do differ slightly from those of Kretschmer \& Cohen (1979) in showing that the frequency at room temperature is higher than at $30^{\circ} \mathrm{C}$.

Similarly, Table 1 shows that there can be no doubt that transposition of $\operatorname{Tn} 21, \operatorname{Tn} 501, \operatorname{Tn} 1721, \operatorname{Tn} 2501$ and $\operatorname{Tn} 3926$ is also temperature-sensitive: all except $\operatorname{Tn} 21$ gave very low or undetectable transposition at $42^{\circ} \mathrm{C}$ and $37^{\circ} \mathrm{C}$, while transposition of $\operatorname{Tn} 21$ was undetectable at $42^{\circ} \mathrm{C}$ and occurred at a reduced frequency at $37^{\circ} \mathrm{C}$ (indeed, although the reported frequency at $37^{\circ} \mathrm{C}$ for Tn 21 is quite high, four of the six clones tested actually showed no detectable transposition - see Table 1). The temperature at which the highest frequency occurred varied: with $\mathrm{Tn} 501$ the frequency at $30^{\circ} \mathrm{C}$ was higher than at room temperature; with $\operatorname{Tn} 1721$ and $\operatorname{Tn} 2501$ the frequencies at these two temperatures were not significantly different; and with $\operatorname{Tn} 3, \operatorname{Tn} 21$ and $\operatorname{Tn} 3926$ the frequency at room temperature was higher than that at $30{ }^{\circ} \mathrm{C}$.

Temperature-sensitivity of transposition thus seems to be a general property of class II transposable elements:
Table 1. Effect of temperature on transposition frequencies of class II transposable elements

\begin{tabular}{|c|c|c|c|c|}
\hline \multirow[b]{2}{*}{$\begin{array}{l}\text { Transposon } \\
\text { (plasmid)* }^{*}\end{array}$} & \multicolumn{4}{|c|}{$10^{7} \times$ Frequency $\dagger$ at: } \\
\hline & $\begin{array}{l}\text { Room temp. } \\
\left(20-24^{\circ} \mathrm{C}\right)\end{array}$ & $30^{\circ} \mathrm{C}$ & $37^{\circ} \mathrm{C}$ & $42^{\circ} \mathrm{C}$ \\
\hline $\begin{array}{l}\text { Tn3 } \\
\text { (pUB2583) }\end{array}$ & $\begin{array}{c}140000(4) \\
(56000-360000)\end{array}$ & $\begin{array}{c}31000(4) \\
(19000-50000)\end{array}$ & $\begin{array}{c}460(5) \\
(410-520)\end{array}$ & $\begin{array}{c}0.24(5) \\
(0.06-0.9)\end{array}$ \\
\hline $\begin{array}{l}\text { Tn21 } \\
\text { (pUB837) }\end{array}$ & $\begin{array}{c}200000(6) \\
(110000-380000)\end{array}$ & $\begin{array}{c}3000(6) \\
(190-47000)\end{array}$ & $\begin{array}{c}930(6) \ddagger \\
(240-3600)\end{array}$ & $<0.5$ (4) \\
\hline $\begin{array}{l}\text { Tn501 } \\
\text { (pVS982) }\end{array}$ & $\begin{array}{c}422(6) \\
(250-705)\end{array}$ & $\begin{array}{c}1600(4) \\
(420-5800)\end{array}$ & $<0.5(6)$ & $<0 \cdot 8(5)$ \\
\hline $\begin{array}{l}\text { Tn } 1721 \\
\text { (pJOE105) }\end{array}$ & $\begin{array}{c}590(6) \\
(230-1500)\end{array}$ & $\begin{array}{c}930(4) \\
(650-1300)\end{array}$ & $\begin{array}{c}0.23(6) \S \\
(0.06-0.96)\end{array}$ & $0 \cdot 02(6) \|$ \\
\hline $\begin{array}{l}\text { Tn } 2501 \\
\text { derivative } \\
\text { (pUB4888) }\end{array}$ & $\begin{array}{c}9730(4) \\
(5000-19000)\end{array}$ & $\begin{array}{c}7300(6) \\
(2200-24000)\end{array}$ & $<0 \cdot 3(6)$ & $2 \cdot 5(6) \uparrow$ \\
\hline $\begin{array}{l}\text { Tn3926 } \\
\text { (pCL17) }\end{array}$ & $\begin{array}{c}57000(5) \\
(2200-1500000)\end{array}$ & $\begin{array}{c}1400(6) \\
(420-4500)\end{array}$ & $<0.4(6)$ & $<0 \cdot 3(5)$ \\
\hline
\end{tabular}

* Plasmid pUB2583 $\left(\mathrm{Cm}^{r} \mathrm{Tc}^{r} \mathrm{Ap}^{r}\right)$ is a pACYC184::Tn3 recombinant (Heritage \& Bennett, 1984). Plasmid pUB837 (Tc ${ }^{r} \mathrm{Ap}^{r} \mathrm{Hg}^{\mathrm{r}} \mathrm{Str}^{\mathrm{r}}$ $\left.\mathrm{Su}^{r}\right)$ is a pBR322: $: \mathrm{Tn} 21$ recombinant, and pVS982 $\left(\mathrm{Tc}^{r} \mathrm{Ap}^{r} \mathrm{Hg}^{\mathrm{r}}\right)$ is a pBR322::Tn501 recombinant (Grinsted et al., 1982). Plasmid pJOE $105\left(\mathrm{Tc}^{r} \mathrm{Ap} \mathrm{p}^{\mathrm{r}}\right)$ is a recombinant of $\mathrm{Tn} 1721$ with a $\mathrm{Tc}^{\mathrm{s}}$ derivative of pBR322 (Schöffl et al., 1981). Tn250I contains no selectable marker. Plasmid pUB4888 $\left(\mathrm{Ap}^{\mathrm{r}} \mathrm{Km}^{\mathrm{r}}\right.$ ) is pTM2 (a recombinant of Tn 2501 with a $\mathrm{Tc}^{\mathrm{s}}$ derivative of $\mathrm{pBR} 322$; Michiels et al., 1987) with the HindIII fragment replaced by the HindIII $\mathrm{Km}^{r}$ fragment of $\mathrm{Tn} 5$. Plasmid pUB4888 is therefore a recombinant derivative of pBR322 with a Tn2501 derivative that is $\operatorname{TnpA}^{-} \mathrm{TnpR}^{-} \mathrm{Res}^{-} \mathrm{Km}^{r}$. A pACYC184:: $\mathrm{Tn} 2501$ recombinant $\left(\mathrm{Cm}^{r} \mathrm{Tc}^{r}\right)$ is present in the same strain to provide transposase in trans. Plasmid pCL17 $\left(\mathrm{Cm}^{r} \mathrm{Tc}^{r} \mathrm{Hg}^{r}\right)$ is a pACYC184:: Tn3926 recombinant (Lett et al., 1985).

$\dagger$ Mean transposition frequencies were determined as follows. All the frequencies for a particular transposon at a particular temperature were converted to their logarithms. The mean and standard deviation of these logs were then determined. Data are quoted as the antilog of this mean, with the spread, indicated below the frequency, being antilog (mean - SD) to antilog (mean + SD). The number of determinations is shown in parentheses to the right of the frequencies.

$\ddagger$ Only two clones gave a detectable frequency, the other four gave no detectable transposition (frequency of $<2 \times 10^{-8}$ ).

$\S$ One of the six clones tested gave no transposition (frequency of $<5 \times 10^{-9}$ ), and two of the clones each produced only a single transconjugant containing transposition products.

\|Only one clone gave a detectable frequency, the other five gave no detectable transposition (frequency of $<6 \times 10^{-9}$ ).

If Only one clone gave a detectable frequency, the other five gave no detectable transposition (frequency of $<3 \times 10^{-8}$ ).

those tested here cover the whole range of elements that have been discovered in Gram-negative bacteria. It has been reported that transposition of $\operatorname{Tn} 1000$ is most efficient at $37^{\circ} \mathrm{C}$ (Tsai et al., 1987). This may be a reflection of the different experimental systems used. It may, however, simply be that the optimum for $\operatorname{Tn} 1000$ is at one extreme of the optima exhibited by class II elements : the data shown in Table 1 demonstrate that the 
optimum temperature for transposition varies, with Tn 501 clearly having a maximum at about $30^{\circ} \mathrm{C}, \mathrm{Tn} 1721$ and $\operatorname{Tn} 2501$ having maxima somewhere between $30^{\circ} \mathrm{C}$ and room temperature, and the others having a lower maximum than this under our experimental conditions. It will be interesting to see how the class II elements that originated in Gram-positive bacteria behave: they diverged from those seen in Gram-negative bacteria a very long time ago (Sherratt, 1989).

Clearly, temperature is an important variable in designing experiments involving measurement of transposition frequencies, and use of the 'normal' $37^{\circ} \mathrm{C}$ to measure transposition of some of the elements shown in the table would not meet with much success. We normally use $30^{\circ} \mathrm{C}$ in experiments involving transposition of class II elements; either transposition frequencies are highest at this temperature, or one has to trade off efficiency of transposition with the rate at which the bacteria grow (at room temperature bacterial growth is slow and incubation for several days is required).

We gratefully acknowledge a Research Studentship from SERC (UK) to A.K.T. and a NATO Collaborative Research Grant to J. G. and F.C., which promoted contacts between the laboratories.

\section{References}

DE la Cruz, F. \& GRINSTED, J. (1982). Genetic and molecular characterisation of $\mathrm{Tn} 21$, a multiple resistance transposon from R100.1. Journal of Bacteriology 151, 222-228.

Grinsted, J., de la Cruz, F., Altenbuchner, J. \& Schmitt, R. (1982). Complementation of transposition of tnpA mutants of Tn3, Tn2l, Tn501 and Tn1721. Plasmid 8, 276-286.

Heritage, J. \& BenNetT, P. M. (1984). The role of $\operatorname{Tn} A$ transposase in transposition immunity. Plasmid 12, 218-221.

KLECKNER, N. (1981). Transposable elements in prokaryotes. Annual Reviews in Genetics 15, 341-404.

KretsChmer, P. J. \& Cohen, S. N. (1979). Effects of temperature on translocation frequency of the Tn3 element. Journal of Bacteriology 139, 515-519.

LETT, M.-C., BENNETT, P. M. \& Vidon, J.-M. (1985). Characterization of Tn3926, a new mercury-resistance transposon from Yersinia enterocolitica. Gene 40, 79-91.

Michiels, T., Cornelis, G., Ellis, K. \& Grinsted, J. (1987). Tn2501, a component of the lactose transposon $\mathrm{Tn} 951$, is an example of a new category of class II transposable elements. Journal of Bacteriology 169, 624-631.

SCHÖFfl, F., PüHLER, A. W., Altenbuchner, J. \& SChmitT, R. (1981). The tetracycline resistance transposons $\operatorname{Tn} 1721$ and $\operatorname{Tn} 1771$ have three 38-base pair repeats and generate five-base pair direct repeats. Molecular and General Genetics 181, 87-94.

ShERRATT, D. (1989). Tn 3 and related elements: site-specific recombination and transposition. In Mobile DNA, pp. 163-184. Edited by D. E. Berg \& M. M. Howe. Washington, DC: American Society for Microbiology.

Tsai, M.-M., Wong, R. Y.-P., Hoang, A. T. \& Deonier, R. C. (1987). Transposition of Tn1000: in vivo properties. Journal of Bacteriology 169, 5556-5562. 